\title{
Metallurgy and materials Selection of materials for blast furnace injection using quality indicators \\ http://dx.doi.org/10.1590/0370-44672018720025
}

\author{
Alex Milton Albergaria Campos ${ }^{1}$ \\ http://orcid.org/0000-0002-2338-4751 \\ Katia Novack ${ }^{2}$ \\ Paulo Santos Assis ${ }^{3}$ \\ ${ }^{1}$ Universidade Federal de Ouro Preto - UFOP, \\ Universidade Estadual de Minas Gerais - UEMG, \\ Rede de Materiais-REDEMAT, \\ Ouro Preto - Minas Gerais - Brasil. \\ alexcampos88@yahoo.com.br \\ ${ }^{2}$ Universidade Federal de Ouro Preto - UFOP, Instituto \\ de Ciências Exatas e Biológicas, Departamento de \\ Química, Ouro Preto - Minas Gerais - Brasil. \\ knovack@iceb.ufop.br \\ ${ }^{3}$ Universidade Federal de Ouro Preto - UFOP, Escola de \\ Minas, Departamento de Engenharia Metalúrgica, \\ Ouro Preto - Minas Gerais - Brasil. \\ assis.ufop@gmail.com
}

\section{Introduction}

The injection of pulverized materials in the blast furnace is a technique that started in the first part of XIX century and has continuously evolved until today, mainly regarding the economic aspects. Some materials, such as natural gas, oils and other solid materials have been used for injection as a way to increase the productivity of the blast furnace, resulting in reduction in the consumption of coke or charcoal and an operational stability of the reactor (Rickets, 2000). The material that was established as the main fuel for injection was the mineral coal that is used in various forms (mixture of several types of coal) bringing good productivity results, but its use can be compromised by the availability, its cost and the impacts generated in the environment. In this way, different materials gain importance to be applied in blast furnaces as injection material, mainly when evaluating the costs of these materials that are often just associated with transportation and

\begin{abstract}
The injection of pulverized materials is a technique used in most of the blast furnaces in the world to reduce coke and charcoal consumption. In addition, injection is one of the main variables of the blast furnace heat control. Coal is the most used material for the injection, but some industries have been attempting to use other materials, usually mixtures, in order to reduce the total dependence on it. The quality of the injected material influences some operational parameters, such as the permeability, the heat control, and also the quality of the hot metal produced. Due to these factors, the strategy and quality of these materials should be planned and evaluated using quality indicators to achieve good production, with low cost and environmental impact. In this context, there is a large number of researches on different materials, especially waste from iron and steelmaking processes, among others. Herein, some quality indicators of different materials tested on industrial and laboratory scales were analyzed compared, and the feasibility of using new materials injected into the blast furnace was discussed.
\end{abstract}

Keywords: injection of pulverized materials; quality management; PCI; quality indicators.

preparation (in the case of waste from other processes). In addition, environmental issues have been gaining prominence in recent years, encouraging the research for more sustainable materials (Suopajarvi et al., 2017).

There are more than 400 blast furnaces in the world that practice injection and more than $70 \%$ of them inject some solid material. In Brazil, it started to be used by Acesita for the injection of charcoal fines. Research shows that high injection rates (180-200 kg / $t$ of hot metal) do not generate proportional gains in the consumption of the reducer. In this case, it is better to focus on improving the combustion rate of the injected material which affects the injection rate, bringing financial gains in the production of hot metal. In other words, the search for materials with a higher combustion rate becomes advantageous (Assis, 2003).

The pulverized coal injection technique is known as PCI and consists of injecting pulverized material with preheated air, enriched oxygen or fuel gas, at high pressure through blast furnace tuyers in the combustion zone (Motta, 2016). After the injection, the material burns, generating gases and heat. The main gases generated for the process are $\mathrm{CO}$ and $\mathrm{H}_{2}$ which will reduce the top-loaded metal.

The main advantages of the injection technique can be listed as reduction of costs by replacing coke or charcoal with cheaper materials, reduction of energy consumption, increase of the productivity (due to the possible enrichment of the air injected with oxygen), increase of coking battery life (due to the reduction of the demand of this reducer), as well as a greater operational stability and quality of the hot metal produced.

Most of the carbon dioxide emissions are associated with the consumption of coke $\left(1900 \mathrm{~kg}\right.$ of $\mathrm{CO}_{2} /$ ton of hot metal) and charcoal $(800 \mathrm{~kg}$ of 
$\mathrm{CO}_{2}$ / ton of hot metal), the first coming from a non-renewable source. Therefore, the use of charcoal and biomass for injection can make a viable alternative for the steel industry since the emissions will be relatively smaller and the costs may be associated with only transportation and preparation for injection, when these materials are waste from other processes (Assis et al., 2014).

Some works show the application of plastics in blast furnaces as injection material with good results. However, these plastics need to be separated and prepared for the injection. Some plastics contain chlorine that can harm the structure of the blast furnace (Babich et al., 2016). Some laboratory tests were performed using PET (poly(ethylene terephthalate)) and waste tires. Both materials are potentials to be used as injection material because of their calorific value and chemical similarity with coal. Moreover, they have a lower relative cost. In addition, biomasses are an alternative with great potential not only for the economic aspect, but mainly for the emission balance. Biomasses often consume more $\mathrm{CO}_{2}$ during their growth than when they emit during their burning

\section{Materials and method}

This study was based on a bibliographical review and some variables related to the quality of the raw materials of the process, which were denominated here as quality indicators of raw materials. Next, the influence of each indicator process (Assis et al., 2014).

A traditional way to measure and follow a process (performance, quality) is through indicators based on a measurement system that integrates all the indicators of the organization. Those indicators are very important for controlling processes, introducing improvement, evaluating the process and allowing managers to make a decision based on facts (Marshall, 2012). It is interesting that the injection materials are managed based on quality indicators jointly with the blast furnace productivity indicators, so it is possible to obtain operational control and open doors for new materials that can be used in addition to a development of this productive process. A steel mill is a complex system and its optimization processes involves the management of the organization, its processes and its human resources. The development of these processes are increasingly influential in the efficiency of the business, so it is necessary that the management of the organization walks parallel to the processes, measuring and evaluating the results (Jovanovic et al., 2016).

There are some properties of the material that can be measured before injection and can be considered as quality indicators, being able to evaluate its performance and support the decisions in the blast furnace operation. It is possible to list some properties of injection materials and associate their effect to the blast furnace. Some of them are: Carbon, ash and moisture content, granulometry, volatile content and others. It is necessary to control the injection system in blast furnaces in order to minimize all possible types of instantaneous variations that may occur in the process.

The aim of this study is to evaluate and compare some aspects related to the quality of the raw material used in the blast furnace injection process. As specific objectives, some quality indicators used to select materials for the injection will be addressed. In addition, some data obtained from pilot scale experiments with data from the use of different types of coals commonly used in industry will be compared. With this, it will be possible to analyze the importance of evaluating the raw material quality indicators in the choice of the most cost-effective material for injection. on the blast furnace replacement ratio was evaluated. The replacement ratio is an important indicator of the reduction process of the ironmaking process, since it shows the gain that is acquired with the use of the injection process. Table 1 presents data obtained from studies of material characterization for injection on a pilot scale, as well as the calculation of the corrected replacement ratio whose equation is according to Brouwer and Toxopeus (1991).

Table 1

Characterization of some materials for blast furnace injection.

\begin{tabular}{c|c|c|c|c|c|c|c} 
Material & $\%$ ash & $\%$ Volatiles & $\% \mathrm{C}$ & $\% \mathrm{H}$ & $\%$ Moisture & Replacement ratio & References \\
\hline Charcoal 2 & 1.90 & - & 84.70 & 3.35 & 4.5 & 0.93 & Wang et al., 2015 \\
\hline Coal 1 & 8.40 & 19.7 & 80.30 & 4.01 & 0.96 & 0.92 & Assis et al., 2014 \\
\hline Waste Plastic & 6.00 & 80.00 & 61.0 & 14.0 & 2.00 & 0.90 & Baich et al., 2016 \\
\hline Coal 2 & 16.23 & 9.32 & 74.2 & 2.54 & 0.79 & 0.79 & Guo et al., 2013 \\
\hline Charcoal 1 & 7.73 & 25.80 & 69.7 & 3.20 & 4.73 & 0.63 & Assis et al., 2014 \\
\hline Pine Torrefied & 3.20 & - & 58.00 & 5.30 & 7.7 & 0.41 & Wang et al, 2015. \\
\hline Eucalyptus Husk & 2.43 & 68.73 & 50.10 & 5.42 & 5.77 & 0.23 & Assis et al., 2014 \\
\hline Bamboo & 1.08 & 78.76 & 48.64 & 5.64 & 5.76 & 0.19 & Du et al., 2014 \\
\hline Coffe Husk & 7.57 & 74.79 & 44.10 & 5.38 & 6.94 & 0.14 & Assis et al., 2014 \\
\hline Sugarcane Bagasse & 4.33 & 75.03 & 46.40 & 4.68 & 7.03 & 0.13 & Du et al., 2014 \\
\hline Elephant Grass & 13.50 & 69.95 & 40.00 & 5.36 & 7.81 & 0.10 & Assis et al., 2014 \\
\hline Rice Rusk & 9.55 & 73.18 & 43.4 & 4.33 & 8.00 & 0.10 & Du et al., 2014 \\
\hline
\end{tabular}

Table 2 shows some data of different coals and mixtures of coals injected in the blast furnace of a company. It contains some actual operating data and the quality of the different injected materials, which were evaluated and compared with the 
materials tested in pilot scale. This comparison is important to demonstrate that is possible to replace part of coal used in the blast furnace injection or even doing some mixture of coal and another material with low cost.

Table 2

Characterization of coals usually used for blast furnace injection. (Assis, 2016)

\begin{tabular}{|c|c|c|c|c|c|c|}
\hline Coal & $\%$ ash & $\%$ Volatile & $\% C$ & $\% \mathrm{H}$ & Injection Rate (Kg/t of hot metal) & Replacement ratio \\
\hline Monopol EB & 6.60 & 15.30 & 83.30 & 4.20 & 52.00 & 0.94 \\
\hline Achenbach & 7.80 & 23.10 & 81.20 & 4.70 & 78.20 & 0.84 \\
\hline Lohberg & 6.60 & 32.30 & 79.00 & 5.00 & 122.20 & 0.88 \\
\hline Monopol GFI & 11.30 & 31.20 & 72.70 & 4.80 & 79.00 & 0.82 \\
\hline Linhito & 6.40 & 51.30 & 58.30 & 5.30 & 97.30 & 0.47 \\
\hline Carborat & 10.00 & 9.10 & 81.20 & 3.60 & 115.20 & 0.87 \\
\hline $50 \%$ Antracito $+50 \%$ Lohberg & 6.90 & 19.10 & 81.80 & 4.40 & 140.00 & 0.84 \\
\hline Furst Leopold & 6.20 & 33.30 & 77.90 & 5.20 & 135.00 & 0.73 \\
\hline Hew-Acken & 7.50 & 25.20 & 30.60 & 4.70 & 128.00 & 0.79 \\
\hline 50\%Hew-Acken +50\%Monopol GFI & 9.40 & 27.10 & 77.50 & 4.70 & 141.70 & 0.75 \\
\hline 70\%Hew-Acken+30\% Furst Leopold & 7.50 & 26.80 & 80.80 & 4.80 & 109.30 & 0.88 \\
\hline 30\% Hew-Acken+70\% Monopol CK & 8.60 & 29.60 & 77.00 & 4.90 & 114.30 & 0.84 \\
\hline
\end{tabular}

In this study, the data from these two tables was used to compare the properties

\section{Results and discussion}

A simple analysis shows that the replacement ratio increases with the decreasing of moisture, showing that a dry material would be more appropriate for

Figure 1

Moisture and replacement ratio of some pulverized materials.

Another important parameter related to characterizing materials for injection through tuyers is the carbon content. The graph presented in

Figure 2

Relationship between carbon content and replacement ratio. between these materials and the effect of each in the replacement ratio of blast furnace.

injection (Figure 1). In addition, a material with high moisture content would bring problems in the transport and injection and a greater reduction of the

\% Moisture

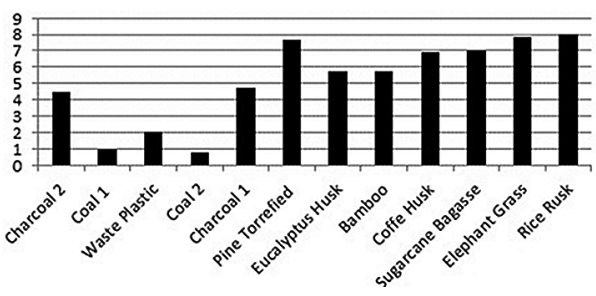

Figure 2 shows that the calculated replacement ratio increases with the carbon content. The carbon content is directly linked to the combustion rate, flame temperature. For a material with a higher moisture content, it is interesting to improve the drying of this material so that it can achieve better efficiency.

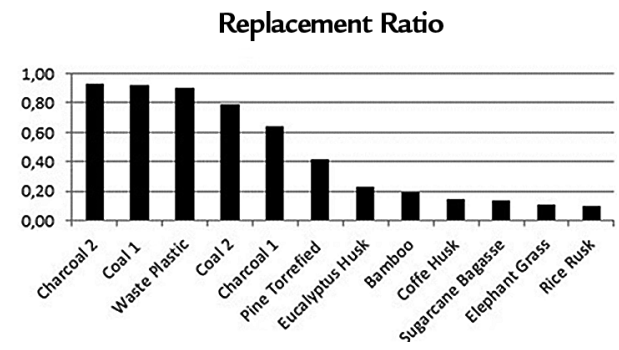

providing desired conditions in the blast furnace. This parameter may indicate new materials and alternatives to the injection, as shown below.

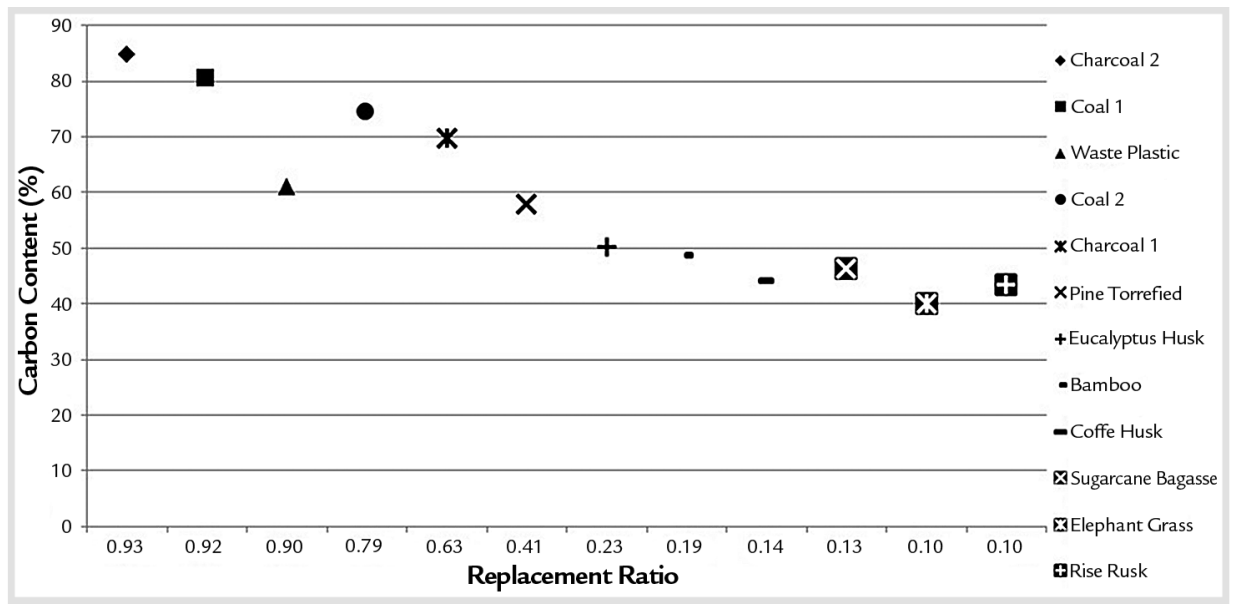


Figure 3 shows how important the analysis of the carbon content in the materials is. It is possible to see that the material with the high- est percentage of carbon (Monopol EB) provided the best replacement ratio. Of course, other parameters contribute to this performance, but the coal quality indicator, \% C, can be analyzed to select materials for the blast furnace injection.
\%C

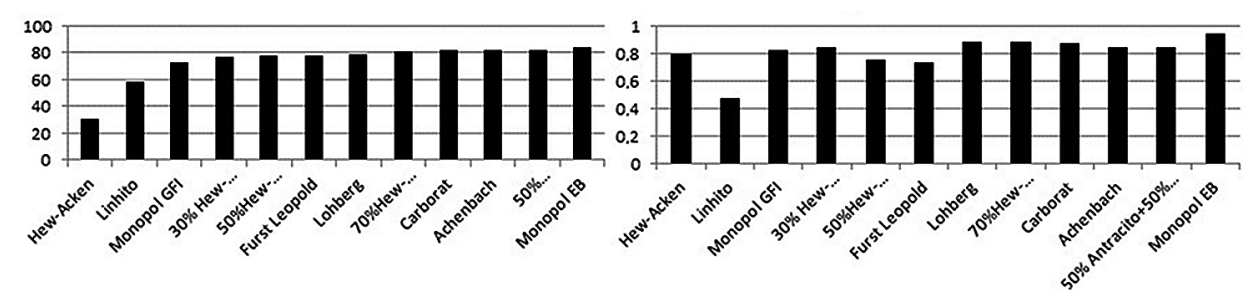

Figure 3

Carbon content and replacement ratio of coals used in blast furnaces.

Figure 4 shows the relationship between the injection rate and the replacement ratio of coal used in blast furnaces.

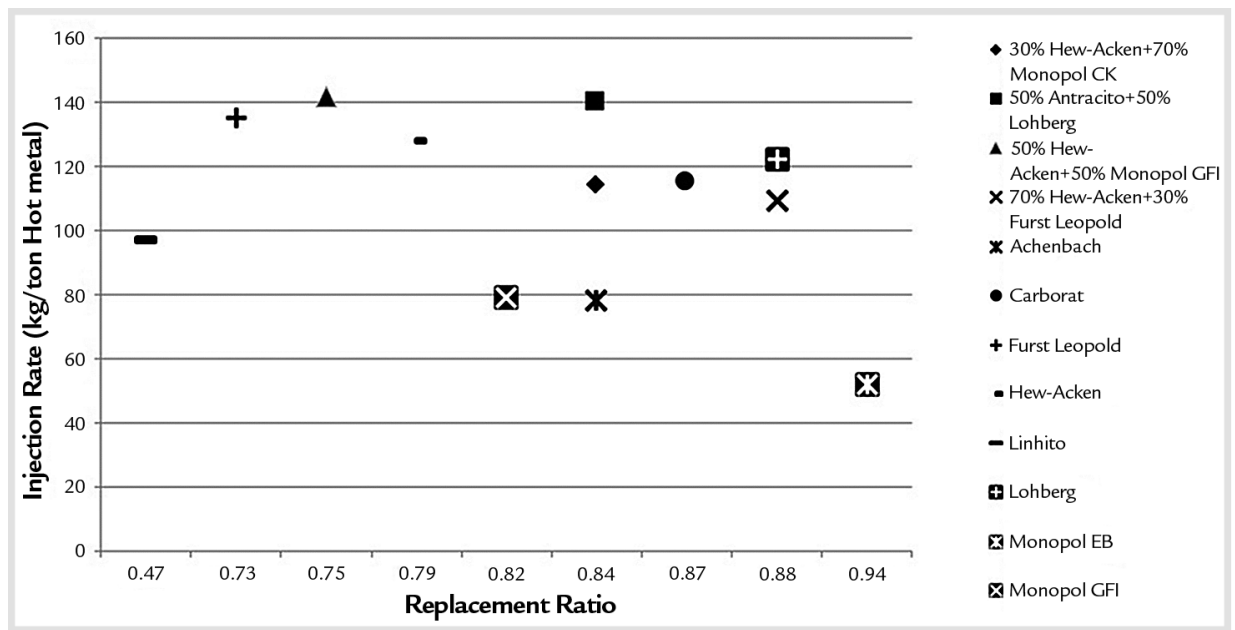

It is interesting to note that the replacement ratio is not directly linked to the injection rate, which means that the amount of material injected is not as important as the quality of the material injection. High

\section{Conclusions}

The injection of pulverized materials in the blast furnace by the tuyers is a consolidated technique and presents gains for the operation of the blast furnace and reduces the production cost of hot metal. According to literature, there is not a single generalized relationship to describe the replacement ratio in blast furnaces. Each blast furnace has its peculiarities, and a very careful analysis is necessary to select relevant variables in the process, in order to obtain optimal operation. The parameters to evaluate the relationship of the material injected and its contribution in the blast furnace are: carbon content, injection rates require a change in blast furnace operation and can cause some phenomena like the bird nest. In addition, it is important to produce hot metal consuming the minimum of material possible, not calorific value, volatile material, ash content, among others. The replacement ratio is inversely proportional to the injection rate, as well as the ash content and volatile material, and is directly proportional to the carbon content and the calorific value of the material.

The injection of fuels such as biomass and other wastes can be a viable alternative because they have lower cost and deal with environmental issues. With determined and evaluated indicators, these new materials can gain more space in this process, bringing savings to companies, as well as valuing the
Figure 4

Relation between the replacement ratio and injection rate of different coals from industry.

only from the top but also from the tuyers. It was observed that the lower injection rate applied was the one that brought a better replacement ratio, due to the high quality of the coal used (Monopol EB). image between environmental agencies and society.

Finally, it is important to say that the determination and evaluation of material quality indicators for injection is necessary to ensure the quality of the process. By evaluating these indicators, it is possible to predict their effects in the blast furnace, as well as to insert the process into a continuous improvement cycle, providing gains for operation and for the final product. In addition, material quality indicators open up possibilities for consistent studies of new injection materials in blast furnaces.

\section{Acknowledgments}

The authors acknowledge CAPES, CNPq, REDEMAT and all that contribute in some way to this work. 


\section{References}

ASSIS, P. S., MARTINS, W., BATISTA, C. Avanços na injeção de carvões pulverizados para sua aplicação em altos-fornos. REM - Revista Escola de Minas, v. 56, n. 4, p. 281-285, 2003.

ASSIS, C., TENÓRIO, J., ASSIS, P., NATH, N. Experimental simulation and analysis of agricultural waste injection as an alternative fuel for blast furnace. ACS Energy \&.Fuels, v. 28, p. 7268-7273, 2014.

ASSIS, P. S. Injeção de materiais pulverizados em altos-fornos: curso de mestrado em engenharia de materiais. Rede Temática de Materiais, 2016.30 p. (Notas de aula).

BABICH, A., SENK,D., KNEPPER,M., BENKERT, S. Conversion of injected waste plastic in blast furnace. Institute of Materials Minerals and Mining - Ironmaking and Steelmaking, v. 43, n. 1, 2016.

BROUWER, R., TOXOPEUS, H. Massive coal injection at Hoogovens Ijmuiden BFs. Revue de Metallurgie, Cahiers d'Informations Techniques, v. 88, n. 4, 1991.

DU, S., CHEN, W., LUCAS, J. Pretreatment of biomass by torrefaction and carbonization for coal blend used in pulverized coal injection. Bioresource Technology, v. 161, p. 333-339, 2014.

GUO, H., SU, B., ZHANG, J., ZHU, M., CHANG, J. Extracting the core indications of pulverized coal for blast furnace injection based on principal component analysis. International Journal of Minerals, Metallurgy and Materials, v. 20, n. 3, p. 246, 2013.

JOVANOVIC, F., BERIC, I., JOVANOVIC, P., JOVANOVIC, D. Risk managemente of energy efficiency projects in the industry-sample plant for injecting pulverized coal into the blast furnace. Thermal Science, v. 20, n.1, p.315-325, 2016.

MARSHALL, I., ROCHA, A. V., MOTA, E. B., QUINTELLA, O. M. Gestão da qualidade e processos. Rio de Janeiro: FGV, 2012. 204 p.

MOTTA, R. Sistemas de injeção de materiais pulverizados em altos-fornos $e$ aciarias. São Paulo: Blucher, 2016. 393p.

RICKETTS, J. History of ironmaking. Warrendale: Iron\&Steel Society, 2000. 194p.

SUOPAJARVI, H., KEMPPAINEN, A., HAAPAKANGAS, J., FABRITIUS,T. Extensive review of the opportunities to use biomass-based fuels in iron and steelmaking processes. Journal of Cleaner Production, v.148, p.709-734, 2017.

WANG, C., MELLIN, P., LOVGREN, J., NILSSON, L., YANG, W., SALMAN, H., HULTGREN,A., LARSSON,M. Biomass as blast furnace injectant-Considering availability, pretreatment and deployment in the Swedish steel industry. Energy Conversion and Management, v. 102, p. 217-226, 2015.

Received: 20 February 2018 - Accepted: 19 July 2018. 